Acta Biologica Plantarum Agriensis 5(1): 49 (2017) ISSN 2061-6716 (Print), 2063-6725 (Online) http://abpa.ektf.hu/
DOI:10.21406/abpa.2017.5.1.49

$4^{\text {th }}$ CC 2017 Abstract

Poster

\title{
LICHENOLOGICAL AND BRYOLOGICAL CURIOSITIES IN THE PAPUK MT (CROATIA)
}

Lichenológiai és bryológiai érdekességek a Papuk hegységben (Horvátország)

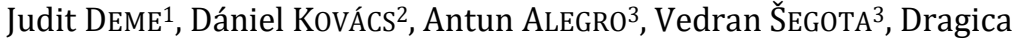 \\ PURGER ${ }^{4} \&$ János CSIKY ${ }^{1}$
}

${ }^{1}$ University of Pécs, Faculty of Sciences, Institute of Biology, Department of Ecology, H-7624

Pécs, Ifjúság u. 6., Hungary; ${ }^{2} \mathrm{H}-2422$ Mezőfalva, Fehérvári út 41., Hungary; ${ }^{3}$ University of Zagreb, Faculty of Science, Division of Biology, Department of Botany, HR-10000 Zagreb, Marulićev trg 20/II, Croatia; ${ }^{4}$ BioRes, H-7624 Pécs, Barackvirág u. 27., Hungary; e-mail: hiddenit92@gmail.hu

In the course of continuous botanical surveys of the Papuk Mt (Slavonia, Croatia) two outstanding sites (Sokolina, near Doljanci and Svinjarevac, by Kamenski Vučjak village) with thermophilic-acidophilous forest have been discovered. This type of oak forest is rather rare in Croatia, but it is dominant at these sites, moreover, stands of the peculiar Fagus sylvatica-Sphagnum quinquefarium forests are also present, so these localities are very unique from the aspect of pedology and phytogeography. Despite the fact that the lichenological survey of Papuk Mt started in the middle of the $19^{\text {th }}$ century the knowledge about lichen flora was very poor, probably because the previous studies focused on the epiphytic species. During our field trips in 2015 and 2016 we collected lichens from different types of substrates and recorded at least 54 taxa. Four of them (e.g. Psilolechia lucida, Umbilicaria polyphylla) were not found in Croatia before and 19 species are new for the lichen flora of the Papuk (e.g. Cladonia cervicornis subsp. verticillata, Pertusaria coronata, Trapeliopsis pseudogranulosa). Umbilicaria hirsuta was detected at Sokolina (second occurrence in Croatia) and the rare Lobaria pulmonaria and Lasallia pustulata were also observed at several new places.

During non-systematic bryological surveys in 2009, 2013, 2015 and 2016, we noticed that the phylogenetic diversity is very high at these sites: species of the classes Bryopsida, Jungermanniopsida, Marchantiopsida and Sphagnopsida (in the case of Sokolina, Andreaeopsida too) occurred together within 100 metres. Several extremely rare species, e.g. Cynodontium polycarpon, Dicranum polysetum, Dicranum spurium, Jamesoniella autumnalis, Jungermannia pumila, Lophozia bicrenata, Pleuridium acuminatum, Rhabdoweisia fugax and new taxa of the Croatian moss flora (e.g. Andreaea rothii ssp. rothii, Buxbaumia aphylla) have been found here. The importance of these sites is indisputable from the aspect of taxonomic diversity, however, the presence of the invasive Campylopus introflexus at Sokolina (second occurrence in Croatia) maybe threaten the taxa growing on soil, with spreading to the detriment of the native species. Since both localities represent highly valuable bryological and lichenological hot spots with very special and unique species assemblages, further research and monitoring of the area is strongly recommended. 